\title{
APLIKASI SISTEM PERPUSTAKAAN TERINTEGRASI DENGAN NOTIFIKASI SMS DAN EMAIL REMINDER
}

\author{
Mercy Hermawati \\ Program Studi Informatika, Universitas Indraprasta PGRI \\ mercy.hermawati@gmail.com
}

\begin{abstract}
Abstrak
Baik dalam organisasi pendidikan maupun organisasi lain, perpustakaan merupakan salah satu fasilitas pendukung yang sangat penting dimana fasilitas ini sebagai wadah atau tempat untuk mencari informasi dalam bentuk format apapunyang dikumpulkan menjadi satu dan dikelola dengan baik oleh suatu organisasi untuk memudahkan para pencari informasi untuk mendapatkannya. Dengan koleksi bahan pustaka yang banyak dan beragam membuat petugas kesulitan untuk menjawab pertanyaan ketersediaan bahan pustaka dan kapan bahan pustaka akan tersedia kembali. Penelitian ini bertujuan untuk mempermudah dalam pencarian informasi bahan pustaka, mempermudah proses peminjaman bahan pustaka, memberikan informasi ketersediaan bahan pustaka dengan lebih cepat dan efektif, memberikan fitur notifikasi informasi perpustakaan terintegrasi dengan sms dan emailreminder.Metode pengumpulan data yang dilakukan dengan studi pustaka, wawancara, observasi dan kuisioner. Metode pengembangan sistem yang digunakan yaitu dengan metode waterfall.Pengujian kualitas sistem menggunakan empat karakteristik kualitas perangkat lunak ISO 9126 yaitu, functionality, reliability, usability dan efficiency.Hasil yang diperoleh adalah aplikasi sistem perpustakaan terintegrasi dengan notifikasi sms dan email reminder sebagai sarana informasi perpustakaan dengan memanfaatkan komputer sebagai alat bantu untuk optimasi layanan perpustakaan, sehingga dapat lebih cepat memenuhi kebutuhan peminjam akan bahan bacaannya dan mempermudah kerja daripada petugas perpustakaan.
\end{abstract}

Kata Kunci : Perpustakaan, Sistem Informasi, Notifikasi, SMS, Email Reminder

\begin{abstract}
Both in educational organizations and other organizations, the library is one of the most important support facilities where this facility as a container or place to find information in any format that is collected into one and managed well by an organization to facilitate the information seekers to get it. With a large and diverse collection of library materials makes it difficult for officers to answer the availability of library questions and when library material will be available again. This research aims to simplify the search for library material information, simplify the process of lending library materials, provide library material availability information more quickly and effectively, providing integrated library information notification feature with sms and email reminder. Methods of data collection conducted with literature study, interviews, observation and questionnaires. System development method used is waterfall method. System quality test using four characteristics of ISO 9126 software quality that is, functionality, reliability, usability and efficiency. The results obtained are integrated library information system with SMS notification and email reminder as library information by using computer as a tool for library service optimization, so it can more quickly fulfill the borrower's need for reading material and simplify the work of library staff.
\end{abstract}

Key Words : Library, Information System, Notification, SMS, Email Reminder

\section{A. Latar Belakang}

\section{PENDAHULUAN}

Perpustakaan secara umum diartikan sebagai kumpulan informasi yang bersifat ilmu pengetahuan, hiburan dan rekreasi untuk kebutuhan manusia.
Teknologiinformasi sudah menjadi bagian dari kehidupan masyarakat luas, dengan mempermudah masyarakat dalam mendapatkan informasi yang cepat dan akurat.Baik dalam organisasi pendidikan maupun organisasi lain, perpustakaan 
merupakan salah satu fasilitas pendukung yang sangat penting dimana fasilitas ini sebagai wadah atau tempat untuk mencari informasi dalam bentuk format apapunyang dikumpulkan menjadi satu dan dikelola dengan baik oleh suatu organisasi untuk memudahkan para pencari informasi untuk mendapatkannya.

Dengan koleksi bahan pustaka perpustakaan yang semakin banyak dan beragam membuat petugas perpustakaan memiliki beberapa kesulitan yaitu petugas kesulitan untuk menjawab apakah bahan pustaka yang dicari tersedia atau tidak, sulit mengetahui kapan bahan pustaka akan tersedia kembali.

Untuk mengatasi masalah tersebut maka diperlukan sistem yang terkomputerisasi dimana sebelumnya pengelolaan masih dilakukan secara manual menggunakan olah database yang hanya dapat dilakukan oleh admin dan dilakukan secara manual dengan menggunakan pembukuan.

Solusi yang ditawarkan yaitu sistem perpustakaan yang didesain lebih fleksibel, efisien dan terstruktur untuk mengatasi kesulitan menjawab ketersediaan kembali bahan pustaka, mengurangi angka keterlambatan pengembalian pustaka serta dapat dengan cepat memenuhi kebutuhan peminjam akan bahan bacaannya adalah aplikasi sistem perpustakaan terintegrasi dengan notifikasi sms dan email reminder yang akan bekerja secara otomatis memberikan informasi pengingat batas pengembalian bahan pustaka, pemesanan bahan pustaka, memudahkan peminjam dalam peminjaman bahan pustaka, memudahkan petugas dalam pengelolaan data pengunjung, anggota dan petugas perpustakaan.

\section{B. Tujuan Penelitian}

Untuk memberikan kemudahan dalam pencarian informasi bahan pustaka, mempermudah proses peminjaman bahan pustaka, memberikan informasi ketersediaan bahan pustaka dengan lebih cepat dan efektif, memberikan fitur notifikasi informasi perpustakaan terintegrasi dengan SMS dan emailreminder.

\section{Manfaat Penelitian}

Manfaat dari penelitian adalah:

1. Memberi kemudahan dalam pengelolaan data pengunjung, anggota dan petugas perpustakaan.

2. Mempermudah dalam pencarian bahan pustaka, mempermudah proses peminjaman, perolehan informasi ketersediaan bahan pustaka dan informasi pemberitahuan berupa notifikasi melalui sms atau emailreminder.

3. Dapat lebih efisien dan fleksibelsehingga cepat memenuhi kebutuhan peminjam akan bahan pustakanya.

\section{Tinjauan Pustaka}

Menurut UU Perpustakaan pada Bab I pasal 1 menyatakan perpustakaan adalah institusi yang mengumpulkan pengetahuan tercetak dan terekam, mengelolanya dengan cara khusus guna memenuhi kebutuhan intelektualitas para penggunanya melalui beragam interaksi pengetahuan.

Perpustakaan adalah suatu kesatuan unit kerja yang terdiri dari beberapa bagian, yaitu bagian pengembangan koleksi, bagian pengolahan koleksi, bagian pelayanan pengguna dan bagian sarana prasarana [1]. Sedangkan menurut [2], "perpustakaan merupakan pusat informasi yang menyediakan beragam pengetahuan dan informasi bagi penggunanya". Perpustakaan dapat juga diartikan sebagai kumpulan informasi yang bersifat ilmu pengetahuan, hiburan dan rekreasi. Oleh karena itu perpustakaan modern telah didefinisikan kembali sebagai tempat untuk mengakses informasi dalam format apapun. 
SMS atau Short Message Service merupakan protocol telekomunikasi yang memungkinkan kita mengirimkan pesan pendek (sebanyak 160 karakter) berupa karakter alfanumerik [3].

SMS gateway memungkinkan kita untuk mengirim dan menerima SMS untuk berbagai keperluan pada aplikasi, misal untuk reminder, notifikasi serta komunikasi.SMS gateway memunginkan untuk mengirimkan dan menerima SMS dari/ ke perangkat bergerak/ telepon seluler ke perangkat lain selain telepon seluler. Adapun aplikasi SMS gateway digunakan untuk menangani atau mengelola pesan SMS dari pengguna dengan aturan tertentu sehingga dapat mengirim/ menerima pesan SMS dari/ke berbagai media (misal: email ke SMS atau sebaliknya) [4].

Email adalah kependekan dari electronic mail. Email adalah sarana kirim mengirim surat melalui jalur internet. E-mail merupakan salah satu proses pengiriman surat melalui internetdengan menggunakan waktu yan sangat singkat dan cepat (+menit).

Pengertian reminder menurut kamus kkbi adalah surat peringatan [5]. Reminder adalah sebuah pesan yang menolong seseorang untuk mengingat sesuatu. Reminder bermanfaat ketika informasi konteksual digunakan untuk menyajikan informasi pada waktu yang tepat dan tempat yang tepat. Reminder dapat digunakan sebagai manajemen waktu yang berfungsi untuk memberi alarm peringatan berupa pemberitahuan berbasis lokasi, waktu maupun catatan yang berupa kontekstual.

\section{METODE PENELITIAN}

\section{A. Metode Pengumpulan Data}

Metode pengumpulan data yang digunakan dalam penelitian ini adalah:

1. Studi Pustaka

2. Wawancara

3. Observasi

\section{Kuisioner}

\section{B. Instrumentasi}

Dalam penelitian ini, instrument yan digunakan untuk mengumpulkan data adalah:

1. Instrument observasi, yaitu dengan melakukan pengamatan langsung di Universitas XYZ.

2. Instrument wawancara ini adalah kepala pusat teknologi dan dosen serta rancangan daftar pertanyaan wawancara.

3. Kuisioner yang digunakan berupa daftar pertanyaan yang diberikan kepada dosen dan mahasiswa.

\section{Teknik Analisis}

Metode pengembangan sistem yang digunakan yaitu metode waterfall, dimana pengembangan ini dilakukan secara berurutan dan linier. Adapun langkah pengembangan metode ini digambarkan sebagai berikut:

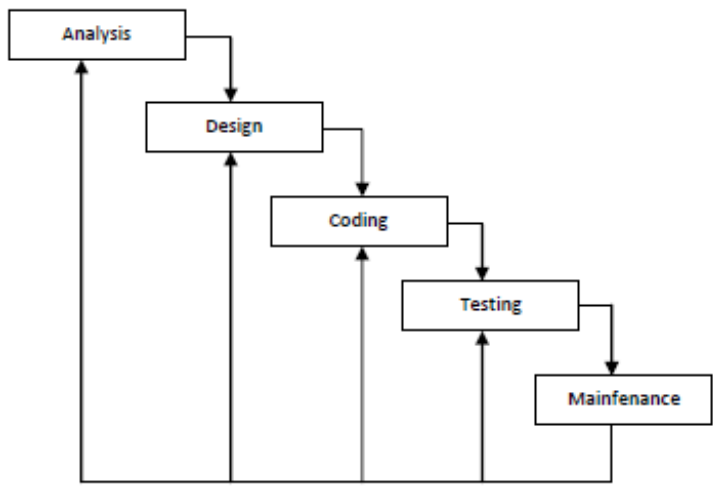

Gambar 1. Tahapan Metode Waterfall

Penjelasan tahapan-tahapan diatas dengan rincian sebagai berikut:

1. Requirement Analysis

Pada tahap ini dilakukan analisa kebutuhan sistem atas sistem yang telah ada dengan merancang sistem yang baru atau diperbarui.Berdasarkan konsultasi dengan pengguna maka dihasilkan kendala yang dihadapi, menetapkan layanan dan tujuan sistem yang kemudian didefinisikan secara rinci dan berfungsi sebagai spesifikasi sistem. 
2. Design

Tahap perancangan sistem dengan mengalokasikan kebutuhan-kebutuhan sistem, perangkat keras maupun perangkat lunak dengan membentuk arsitektur sistem secara keseluruhan. Semua subsistem dalam menyusun aplikasi perpustakaan akan dirancang lebih detail. Mulai dari layout, antar muka inputan, output dan kesemuanya dirancang secara detail.

3. Coding

Pada tahap ini merupakan penerjemahan design ke dalam bahasa yang dikenali komputer, tahapan secara nyata dalam mengerjakan suatu sistem yang dilakukan oleh programmer.

4. Testing

Setelah pengkodean selesai maka akan dilakukan testing terhadap sistem yang telah dibuat. Bertujuan untuk menemukan kesalahan-kesalahan terhadap sistem dan kemudian dapat diperbaiki.

5. Operation \&Maintenance

Pada tahap ini, perangkat lunak yang sudah jadi, dijalankan serta dilakukan pemeliharaan. Termasuk dalam memperbaiki kesalahan yang tidak ditemukan pada langkah sebelumnya. Kesalahan dan kelalaian pada software requirements awal dapat ditemukan.

Kelebihan Metode Waterfall:

Kelebihan menggunakan metode waterfall adalah metode ini memungkinkan untuk departementalisasi dan kontrol. Proses pengembangan model fase one by one, sehingga meminimalis kesalahan yang mungkin akan terjadi. Pengembangan bergerak dari konsep, yaitu melalui desain, implementasi, pengujian, instalasi, penyelesaian masalah, dan berakhir di operasi dan pemeliharaan.

Kekurangan Metode Waterfall:

Kekurangan menggunakan metode waterfall adalah metode ini tidak memungkinkan untuk banyak revisi jika terjadi kesalahan dalam prosesnya. Karena setelah aplikasi ini dalam tahap pengujian, sulit untuk kembali lagi dan mengubah sesuatu yang tidak terdokumentasi dengan baik dalam tahap konsep sebelumnya.

\section{HASIL DAN PEMBAHASAN}

A. Analisa Sistem Berjalan

1. Pengunjung hanya boleh membaca di dalam perpustakaan.

2. Hanya anggota yang boleh meminjam bahan pustaka.

3. Jumlah pinjaman maksimal 2 bahan pustaka.

4. Lama pinjaman maksimal 3 hari.

5. Tidak ada denda untuk telat pengembalian, rusak ataupun hilang.

6. Jika telat, rusak atau hilang maka wajib mengganti dengan bahan pustka baru atau mengganti yang rusak atau hilang.

B. Analisa Kebutuhan Fungsional

1. Sistem dapat menyediakan informasi bahan pustaka serta informasi ketersediannya.

2. Sistem menyediakan fitur pencarian bahan pustaka.

3. Sistem menyediakan layanan peminjaman secara online.

4. Sistem memberikan layanan informasi kepada anggota berupa notifikasi dengan mengintegrasikan fitur SMS dan email reminder.

5. Sistem menyediakan fitur sitasi.

6. Sistem dapat melakukan pengolahan data bahan pustaka.

7. Sistem menyediakan fitur rating bahan pustaka yang dipinjam atau disumbangkan.

8. Sistem menyediakan fitur penanadaan bahan pustaka.

\section{Analisa Kebutuhan Non Fungsional}

1. Kebutuhan Perangkat User

Kebutuhan minimum perangkat keras yang dapat digunakan dalam perangkat lunak yang dibuat dari segi user adalah:

a) PC atau Laptop 
b) Monitor VGA yang dapat menampilkan resolusi minimal 800 x 600 pixel

c) Keyboard dan mouse untuk interaksi antar pengguna dengan sistem

d) Modem alat koneksi internet ke server

2. Kebutuhan Perangkat Keras

Kebutuhan minimum perangkat keras yang dapat digunakan dalam perangkat lunak yang dibuat dari segi server adalah:

a) PC Server untuk database

b) PC Server untuk web server

c) PC Server untuk mail server

d) Modem SMS untuk notifikasi

e) Modem untuk jaringan internet atau local koneksi

3. Kebutuhan Perangkat Lunak

Perangkat lunak yang dibutuhkan untuk penunjang applikasi dari segi user adalah:

a) Sistem Operasi Windos, Linux, dll.

b) Browser Mozzila, Google Chrome, Internet Explorer, Safari dll

c) Jaringan Internet

Perangkat lunak yang dibutuhkan untuk penunjang applikasi dari segi server adalah:

a) PHP 5

b) Database MySql

c) Gateway Email receiver dan sender

d) Gateway SMS receiver dan sender

\section{Use Case Diagram}

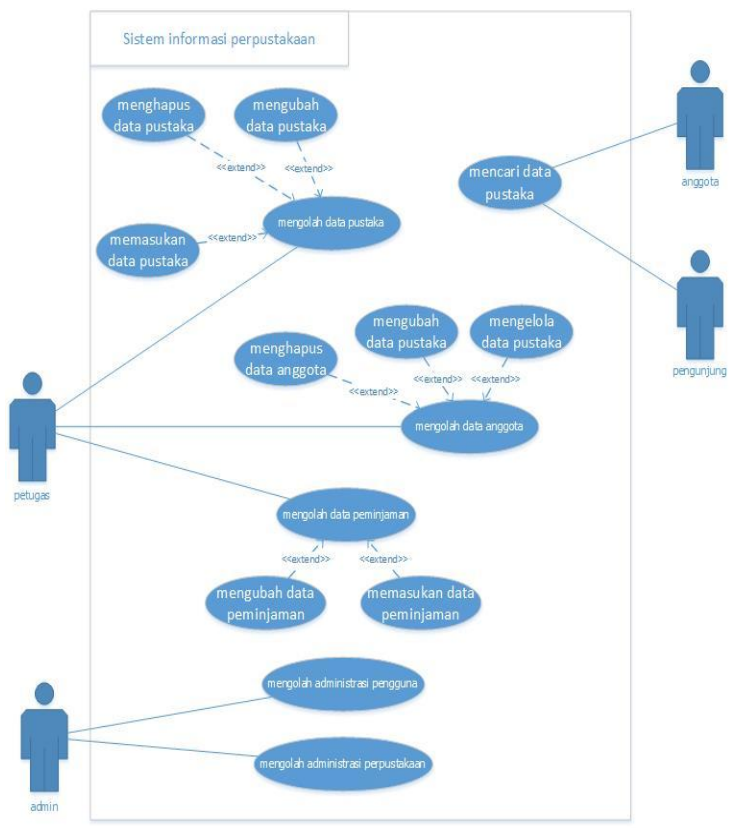

Gambar 2.Use Case Diagram

\section{Identifikasi Aktor}

Admin: Orang yang mengelola sistem informasi secara keseluruhan dan membatasi kinerja dari pegawai yang lainya.

Pengunjung: Pengunjung dapat mencari, melihat, memesan informasi pustaka dan melakukan pendaftaran menjadi angggota perpustakaan secara online.

Anggota: Anggota meliputi mencari, melihat, memesan informasi pustaka, mengedit data diri, adanya fitur notifikasi agar informasi terbaru dapat di dapatkan secara on time. Dapat melihat detail informasi peminjaman dan resensi dalam fitur yang di tawarkan.

Petugas: Petugas sebagai pengelola pustaka meliputi menambah, mengedit pustaka. Melakukan laporan. Melihat detail peminjaman anggota. Melakukan verifikasi anggota. 
E. Use Case Package Diagram
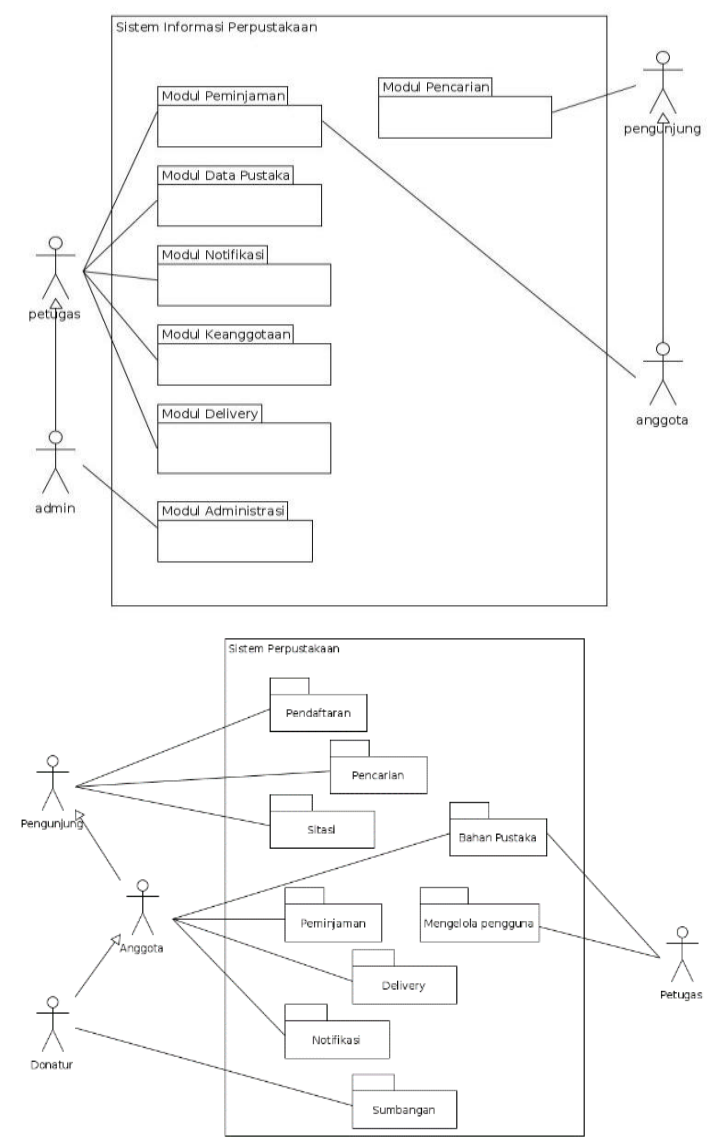

Gambar 3.Use Case Package Diagram

\section{Use Case Description}

1. Pendaftaran

\section{Tabel 1. Pendaftaran}

\begin{tabular}{|l|l|}
\hline Use case description Pendaftaran \\
\hline Use Case & isi form pendaftaran \\
\hline Actor & penguniung \\
\hline Pre-Condition & blm melakukan pendaftaran \\
\hline Post Condition & actor melakukan pendaftaran \\
\hline Description & penguniung melakukan pendaftaran dengan mengisi form \\
\hline \multicolumn{3}{|c|}{ Actor } & \multicolumn{1}{c|}{ Petugas } \\
\hline \multicolumn{3}{|c|}{} & 2. petugas menerima form pendaftaran \\
\hline 1. penguniung isi form pendaftaran & 3. memeriksa data penguniung \\
\hline \multicolumn{2}{|c|}{} \\
\hline
\end{tabular}

\section{Pencarian dan Sitasi}

\section{Tabel 2. Pencarian dan Sitasi}

\begin{tabular}{|l|l|}
\hline use case description pencarian \& sitasi \\
\hline Use Case & cari pustaka \\
\hline Actor & pengunjung \\
\hline Pre-Condition & data blm dicari \\
\hline Post Condition & data sudah dicari atau dapatkan \\
\hline Description & pengunjung mencari bahan pustaka di sistem informasi \\
\hline \multicolumn{3}{|c|}{ Actor } & \multicolumn{1}{|c|}{ system } \\
\hline 1. membuka menu pencarian & 2. menampilkan menu \\
\hline 3. memasukan data pustaka yang dicari & 4.menampilkan bahan pustaka yang dicari \\
\hline 5. mendapatkan id buku yang dicari & \\
\hline
\end{tabular}

3. Bahan Pustaka

Tabel 3. Bahan Pustaka

\begin{tabular}{|c|c|c|}
\hline \multicolumn{3}{|c|}{ use case description bahan pustaka } \\
\hline Use Case & \multicolumn{2}{|c|}{ tambah pustaka } \\
\hline Actor & \multicolumn{2}{|l|}{ petugas } \\
\hline Pre-Condition & \multicolumn{2}{|c|}{ data blm bertambah } \\
\hline Post Condition & \multicolumn{2}{|c|}{ data pustaka bertambah } \\
\hline Description & \multicolumn{2}{|c|}{ petugas menambah data pustaka perpustakaan dengan pustaka vg baru } \\
\hline & Actor & system \\
\hline \multicolumn{2}{|c|}{ 1. memasukan data pustaka baru } & 2. system meyimpan data pustaka kedalam database \\
\hline
\end{tabular}

4. Mengelola Pengguna

Tabel 4. Mengelola Pengguna

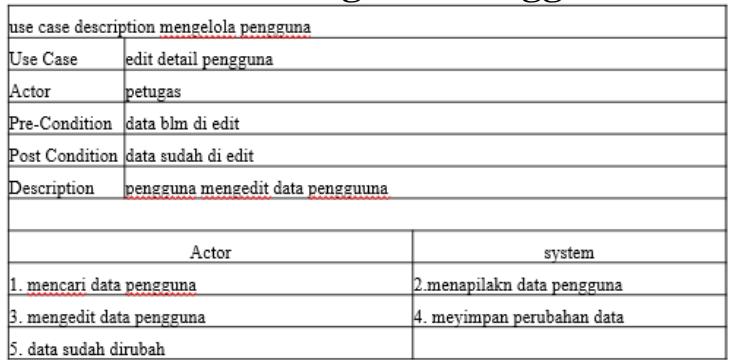

\section{Peminjaman}

\section{Tabel 5. Peminjaman}

\begin{tabular}{|c|c|c|}
\hline Use Case & \multicolumn{2}{|l|}{ piniam buku } \\
\hline Actor & \multicolumn{2}{|l|}{ anggota dan petugas } \\
\hline Pre-Condition & \multicolumn{2}{|l|}{ buku blm teroiniam } \\
\hline Post Condition & \multicolumn{2}{|c|}{ buku sudah terpiniam } \\
\hline Description & \multicolumn{2}{|c|}{ anggota meminiam buku kepada petugas tidak lebih dari 10 copy } \\
\hline \begin{tabular}{|l|l|}
\multicolumn{2}{|c|}{$|c|$} \\
anggota & petugas \\
\end{tabular} & & petugas \\
\hline \multicolumn{2}{|c|}{ 1. memberikan id buku yg akan di pinjam ke petugas } & 2. mencari buku yg akan di piniam anggota. \\
\hline \multirow{2}{*}{\multicolumn{2}{|c|}{ 5. menerima buku }} & 3. memasukan data buku $y g$ di pinjam ke database \\
\hline & & 4.memberikan buku keangoota \\
\hline
\end{tabular}

6. Notifikasi

\section{Tabel 6. Notifikasi}

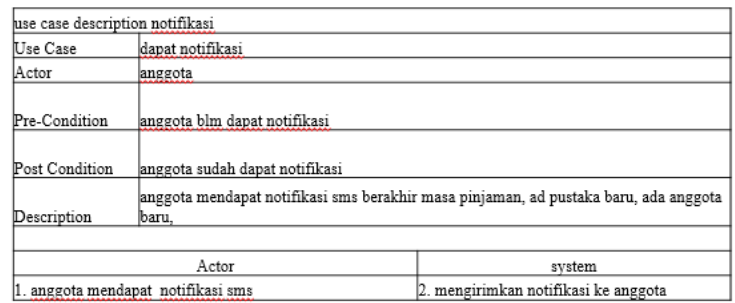

\section{Sumbangan}

Tabel 7. Sumbangan

\begin{tabular}{|c|c|c|}
\hline Use Case & \multicolumn{2}{|c|}{ kirim buku } \\
\hline Actor & \multicolumn{2}{|c|}{ donatur } \\
\hline Pre-Condition & \multicolumn{2}{|c|}{ blm dapat mevumbang buku } \\
\hline Post Condition & \multicolumn{2}{|c|}{ sudah dapat mevumbang buku } \\
\hline Description & \multicolumn{2}{|c|}{ bagi donatur vg ingin mevumbang buku maka otomatis ia alan masuk meniadi anggota } \\
\hline \multicolumn{2}{|c|}{ Actor } & petugas \\
\hline \multirow{2}{*}{\multicolumn{2}{|c|}{ 1.meyumbang buku }} & 2. mencatat data buku dan donatur vg menyumbang \\
\hline & & 3. meximpan kedalam database \\
\hline
\end{tabular}




\section{F. Class Diagram}

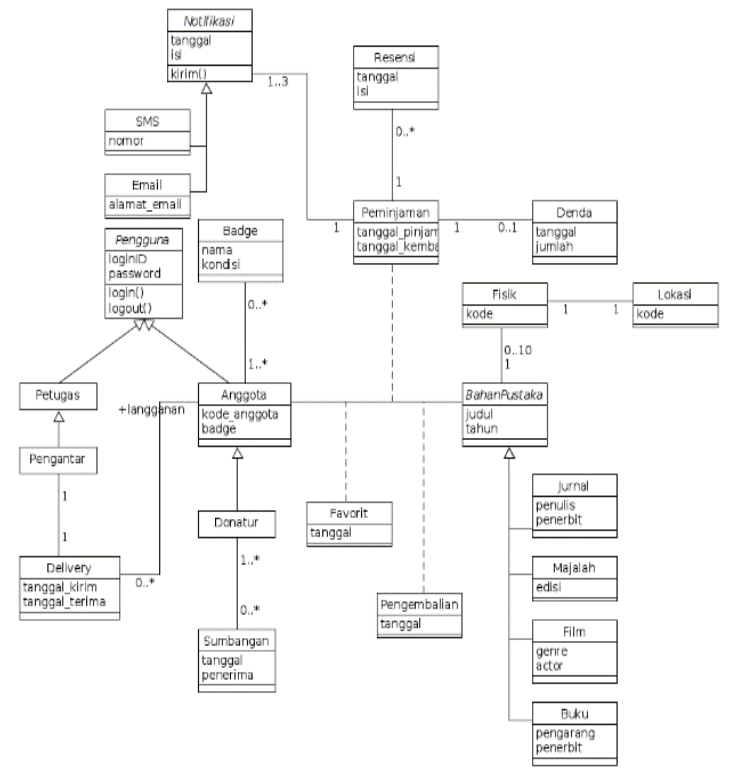

Gambar 4.Class Diagram

\section{G. Struktur Menu}

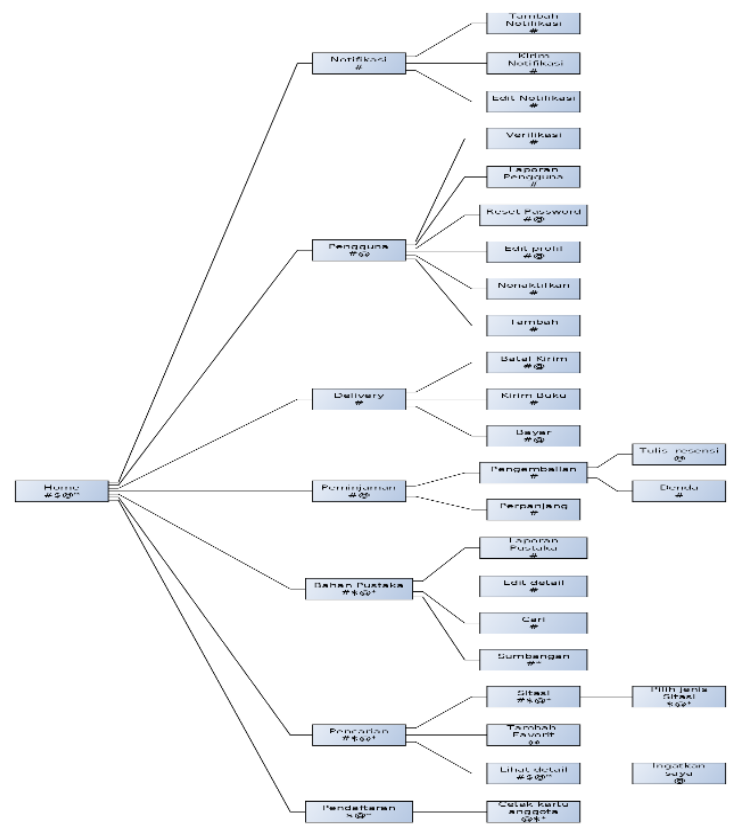

Gambar 5. Struktur Menu

H. Tampilan Sistem

1. Login

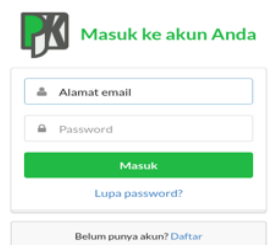

Gambar 6. Login
Tampilan ini adalah tampian layar awal yang akan uncul apabila program dijalankan. Login ini akan masuk dashboard admin apabila login tersebut sukses.

2. User Interface Pengunjung

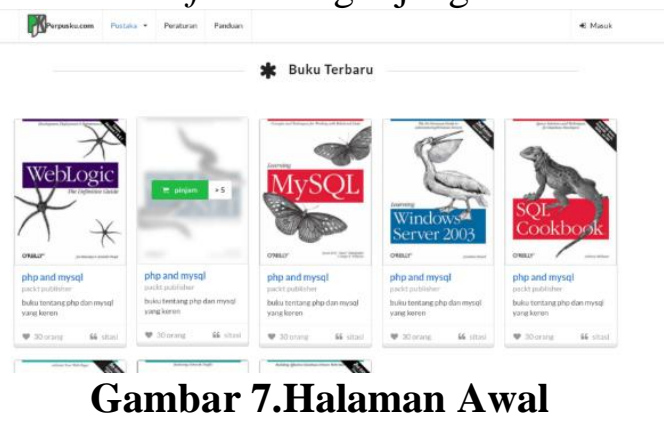

Tampilan ini merupakan halaman awal yang menampilkan bahan pustaka terbaru yang dapat dikunjungi oleh pengunjung perpustakaan. Cukup dengan mengklik gambar buku tersebut pengunjung dapat melihat sitasi dari buku tersebut.

\section{User Interface Petugas}

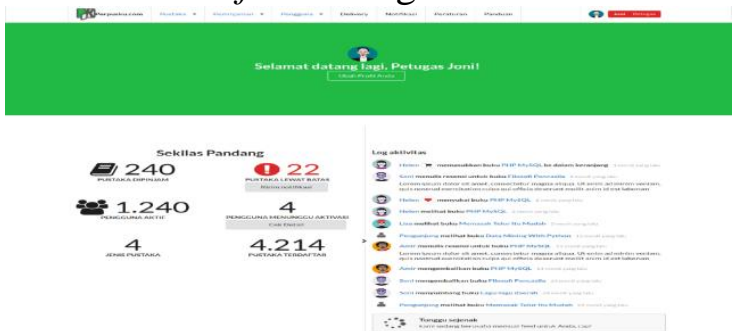

Gambar 8.Dashboard Petugas

Tampilan ini merupakan tampilan halaman dashboard petugas perpustakaan.

4. Tambah Pustaka

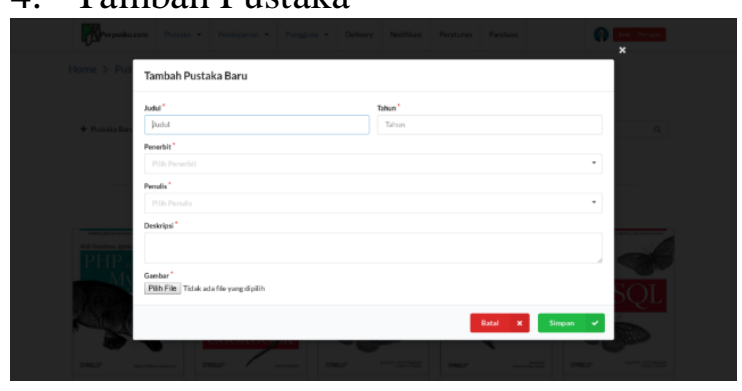

Gambar 9.Tambah Pustaka

Halaman ini berfungsi untuk menambahkan data bahan pustaka yang akan tersedia di sistem perpustakaan. 


\section{Sumbangan}

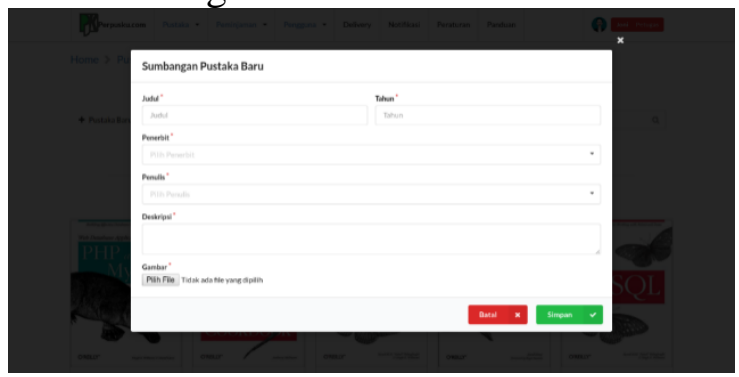

Gambar 10.Sumbangan

Tampilan ini merupakan halaman untuk menginput sumbangan pustaka baru ke dalam sistem perpustakaan

6. Laporan

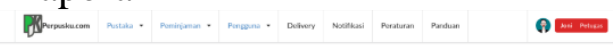

Pilih Jenis Laporan

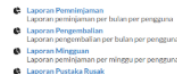

Gambar 11. Laporan

Halaman laporan ini berfungsi untuk melihat perkembangan perpustakaan, seperti melihat dan mencetak data peminjaman pustaka perbulan, data pengembalian pustaka perbulan, data peminjaman perminggu dan pustaka yang mengalami kerusakan.

\section{User Interface Anggota}
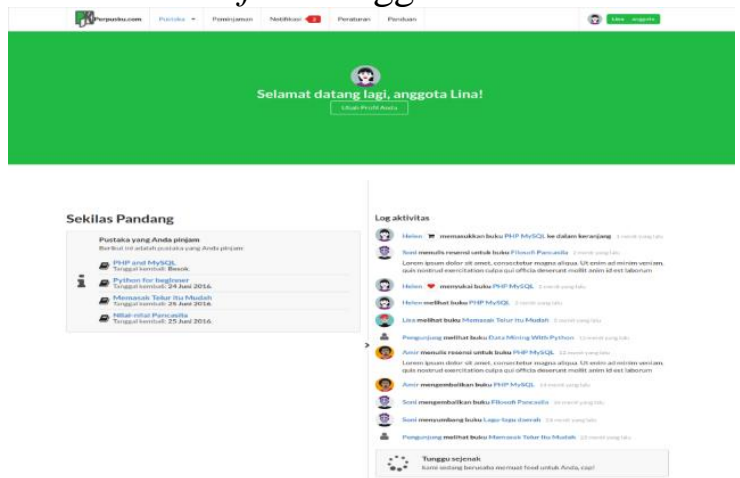

Gambar 12.Dashboard Anggota

Tampilan ini merupakan halaman dashboard petugas perpustakaan.
8. Peminjaman

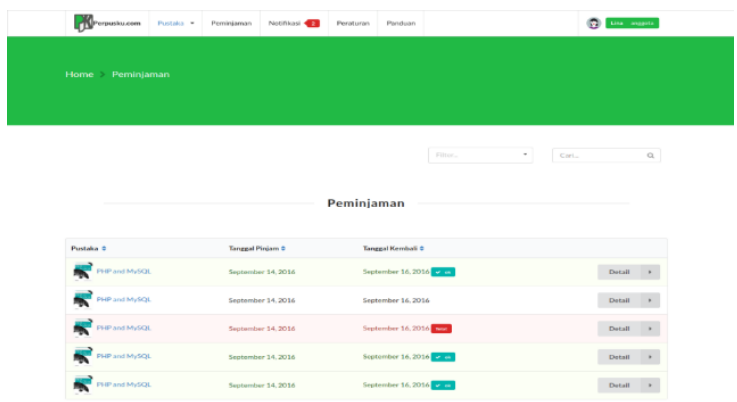

Gambar 13.Peminjaman

Halaman ini menampilkan daftar data pustaka yang dipinjam disertai informasi tanggal pinjam dan tanggal batas pengembalian bahan pustaka.

9. Notifikasi
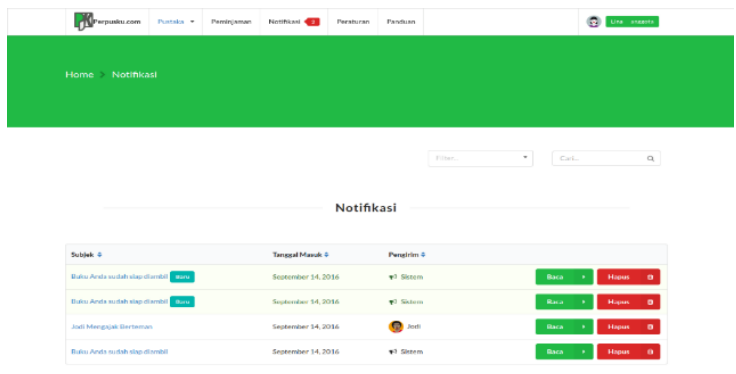

\section{Gambar 14.Notifikasi}

Tampilan ini merupakan halaman fitur informasi notifikasi anggota atas pesanan buku dan batas pengembalian buku.

\section{Pengujian Sistem}

1. Pengujian Validasi

Pengujian validasi untuk melakukan penilaian dalam sistem yang dikembangkan, untuk menjamin bahwa sistem yang dibangun sudah memenuhi persyaratan informasi, fungsional perilaku dan persyaratan kinerja sebelum diserahkan ke pengguna.

Teknik pengujian validasi sistem dilakukan dengan pendekatan blackbox testing dengan metode FGD (Focus Group Discussion). 
2. Pengujian Kualitas

Pengujian kualitas sistem untuk mengetahui kesesuaian yang diharapkan pada aplikasi sistem perpustakaan ini.Pengujian ini menggunakan empat karakteristik kualitas perangkat lunak ISO 9126 yaitu, functionality, reliability, usability dan efficiency. Dari responden yang mengisi kuisioner terhadap tingkat kualitas sistem maka selanjutnya dapat diukur dengan menggunakan rumus sebagai berikut:

$$
\% \text { Skor Aktual }=\frac{\text { Skor Aktual }}{\text { Skor Ideal }} \times 100 \%
$$

Berikut rekapitulasi hasil pengujian kualitas berdasarkan empat aspek kualitas perangkat lunak menurut ISO 9126.

Tabel 8. Hasil Pengujian Kualitas

\begin{tabular}{|l|c|c|c|c|}
\hline \multicolumn{1}{|c|}{ Aspek } & $\begin{array}{c}\text { Skor } \\
\text { Aktual }\end{array}$ & $\begin{array}{c}\text { Skor } \\
\text { Ideal }\end{array}$ & $\begin{array}{c}\% \text { Skor } \\
\text { Aktual }\end{array}$ & Kriteria \\
\hline Functionality & 252 & 300 & $84,00 \%$ & Baik \\
\hline Reliability & 145 & 200 & $72,50 \%$ & Baik \\
\hline Usability & 242 & 300 & $80,66 \%$ & Baik \\
\hline Efficiency & 168 & 200 & $84,00 \%$ & Baik \\
\hline Total & $\mathbf{8 0 7}$ & $\mathbf{1 0 0 0}$ & $\mathbf{8 0 , 7 0 \%}$ & Baik \\
\hline
\end{tabular}

Berdasarkan tabel diatas dapat disimpulkan bahwa tingat kualitas perangkat lunak aplikasi sistem perpustakaan secara keseluruhan memiliki skor nilai aktual sebesar $80,70 \%$ dan skor ideal sebesar 1000 serta memiliki presentase sebesar $80,70 \%$ dengan kriteria baik. Aspek kualitas tertinggi berada pada aspek functionality dan efficiency dengan presentasi sebesar 84\%, selanjutnya aspek urutan ketiga berada pada aspek usability dengan presentase sebesar $80,66 \%$ dan aspek terendah berada pada aspek reliability dengan presentase $72,50 \%$.

\section{SIMPULAN DAN SARAN}

Berdasarkan uraian diatas maka dapat diambil kesimpulan sebagai berikut:

1. Perancangan dan implementasi "aplikasi sistem perpustakaan terintegrasi dengan notifikasi SMS dan email reminder" dapat digunakan sebagai media penyampaian informasi atas pemesanan dan pengembalian bahan pustaka yang diharapkan dapat memudahkan pencarian informasi ketersediaan bahan pustaka dan dapat mengurangi angka keterlambatan pengembalian bahan pustaka.

2. Apikasi sistem perpustakaan dapat memberikan informasi ketersediaan bahan pustakanya dengan lebih fleksibel, efisien dan terstruktur sehingga cepat memenuhi kebutuhan peminjam akan bahan bacaannya serta sistem mempermudah kerja dari petugas perpustakaan.

3. Hasil pengujian aplikasi sistem perpustakaan yang diukur berdasarkan empat karakteristik kualitas perangkat lunak ISO 9126 yaitu dengan mendapat presentase $80,70 \%$ dengan kriteria baik.

Saran yang dapat diberikan untuk institusi dan penelitian selanjutnya yaitu:

1. Perlu adanya keamanan sistem untuk menjaga integritas data yang terkandung dalam sistem tersebut karenasistem ini terkoneksi dengan jaringan komputer dan internet.

2. Aplikasi dapat dikembangkan dengan berbasis android atau IOS.

\section{DAFTAR PUSTAKA}

[1] Rahayuningsih, F. Pengelolaan Perpustakaan. Yogyakarta: Graha Ilmu. 2007.

[2] Sinaga, D. Mengelola Perpustakaan Sekolah. Jakarta: Kreasi Media Utama. 2007.

[3] Nurlaela, Fetty. Aplikasi SMS Gateway Sebagai Sarana Penunjang Informasi Perpustakaan Pada Sekolah Menengah Pertama Negeri 1 Arjosari. Indonesian Journal on Networking and Security, 2013; 2(4):20-25.

[4] Painem. Rancangan Push Information Pembayaran Sekolah Menggunakan SMS Gateway : StudiKasus SMK 
Bina Insan Mandiri Jakarta. Jurnal Telematika MKOM, 2010; 2(2): 126135.

[5] Kamus Besar Bahasa Indonesia: http://www.kamuskbbi.id/(Diakses 23 Maret 2018)

[6] Pressman, Roger S. Rekayasa Perangkat Lunak-Buku Satu, Pendekatan Praktisi, Edisi ke7. Yogyakarta: Andi.2012.

[7] Sutarno NS. Perpustakaan dan Masyarakat. Jakarta: Sagung Seto. 2006. 